\title{
PENERAPAN KOMPUTASI HIJAU DI LINGKUNGAN PEMERINTAH DAERAH DAN PERUSAHAAN BIDANG TEKNOLOGI INFORMASI
}

\author{
Badar Agung Nugroho \\ Balai Pengkajian dan Pengembangan Komunikasi dan Informatika (BPPKI) Bandung \\ Jl. Padjadjaran No. 88 Bandung, Jawa Barat - 40173 \\ email:agung.badar@gmail.com \\ Naskah diterima tanggal 30 Mei 2013, disetujui pada tanggal 24 Juni 2013
}

\section{GREEN COMPUTING IN LOCAL GOVERNMENTS AND INFORMATION TECHNOLOGY COMPANIES}

\begin{abstract}
Green computing is a study and practice of designing, manufacturing, using, and disposing of information and communication devices efficiently and effectively with minimum impact on the environment. If the green computing concept was implemented, it will help the agencies or companies to reduce energy and capital cost from their IT infrastructure. The goal from this research is to explore the current condition about the efforts from local governments and IT companies at West Java to implement the green computing concept at their working environment. The primary data were collected by using focus group discussion by inviting the local governments and IT companies representatives who responsible to manage their IT infrastructure. And then, the secondary data were collected by doing brief observation in order to see the real effort of green computing implementation at each institution. The result shows that there are many different perspectives and efforts of green computing implementation between local governments and IT companies.
\end{abstract}

Keywords: green computing, local government, IT companies.

\begin{abstract}
Abstrak
Komputasi hijau merupakan studi dan pelaksanaan dari suatu desain, pembuatan, penggunaan, pengolahan dari perangkat-perangkat teknologi informasi dan komunikasi dengan cara yang efektif dan efisien yang berdampak kecil terhadap lingkungan. Jika konsep tersebut dilaksanakan akan membantu instansi atau perusahaan dalam menekan biaya pengeluaran sumber daya untuk infrastruktur ITnya. Tujuan dari penelitian ini adalah untuk mengetahui gambaran dari upaya penerapan komputasi hijau di lingkungan pemerintahan dan sektor bisnis terutama di bidang TIK. Pengumpulan datanya dilakukan dengan diskusi kelompok terarah/focus group discussion, dengan perwakilan pada kedua elemen instansi tersebut (pemerintahan dan bisnis). Selanjutnya dilakukan observasi di setiap instansi yang menjadi sampel penelitian untuk melihat penerapan konsep komputasi hijau yang ada. Hasil penelitian menunjukkan, terdapat perbedaan dari kedua elemen tersebut terlihat berbeda pada setiap faktornya. Perbedaan pola kerja, tingkat pengetahuan, kebijakan sampai dengan infrastruktur dari kedua elemen tersebut membuat penerapan konsep komputasi hijau pada kedua lingkungan kerja terlihat berbeda.
\end{abstract}

Kata kunci: komputasi hijau, pemerintah daerah, perusahaan bidang teknologi, dan informasi. 


\section{PENDAHULUAN}

Komputasi hijau (Green Computing) yang dikenal juga dengan istilah Green Information Technology (Green IT). Dalam pengertiannya, Green IT merupakan studi dan pelaksanaan dari suatu desain, pembuatan, penggunaan, pengolahan dari komputer, server, dan perangkat terkait di dalamnya seperti monitor, printer, perangkat penyimpanan data, perangkat komunikasi jaringan dengan cara yang efektif, efisien yang berdampak kecil (tidak berdampak) terhadap lingkungan (Murugesan, 2008).

Pada implementasinya, pelaksanaan Green IT dari suatu instansi/perusahaan dapat membantu instansi tersebut dalam menekan biaya pengeluaran sumber daya untuk infrastruktur ITnya, meningkatkan performa dan penggunaan sistem di dalamnya sejalan dengan proses pelestarian dan tanggung jawab sosial terhadap lingkungan hidup (Murugesan, 2008).

Penelitian ini merupakan kelanjutan dari model dan metode penelitian sebelumnya dengan mengambil sudut pandang yang berbeda. Dalam penelitian ini komparasi dilihat dari dua elemen yang berbeda yaitu regulator dan bisnis. Pemerintah daerah khususnya dari dinas seperti Dinas Komunikasi dan Informatika (Dinas Kominfo) atau kedinasan lain yang mengurusi bidang kominfo merupakan instansi yang berperan menjadi regulator untuk menyusun kebijakan di bidang kominfo pada lingkungan kerja pemerintah daerahnya maupun kebijakan menyeluruh di kawasan kota/ Kabupatennya. Dari sisi bisnis adalah perusahaan-perusahaan di bidang teknologi informasi dan komunikasi (TIK) yang sudah tentu menggunakan perangkat-perangkat TIK dalam kesehariannya dan sebagai aset bagi perusahaan tersebut.

Permasalahan yang akan diangkat dalam penelitian ini adalah bagaimana gambaran dari upaya penerapan komputasi hijau di lingkungan pemerintahan dan sektor bisnis terutama di bidang TIK.

Tujuan dari penelitian ini adalah untuk mengetahui gambaran dari upaya penerapan komputasi hijau di lingkungan pemerintahan dan sektor bisnis terutama di bidang TIK.

Seperti diketahui sampai saat ini kampanye serta program tentang komputasi yang ramah lingkungan masih belum digaungkan baik oleh pemerintah maupun sektor bisnis di Indonesia. Hasil dari penelitian ini diharapkan dapat menjadi masukan bagi kedua sektor terutama bagi Kementerian Komunikasi dan Informatika agar dapat memberikan langkah yang tepat terkait dengan konsep komputasi hijau sehingga kelestarian alam pada kaitannya dengan kemajuan dan pemanfaatan perangkat TIK dapat dijaga oleh seluruh pihak.

\section{LANDASAN KONSEP}

\section{Green Computing}

Green computing (komputasi hijau) sering juga dikenal dengan sebutan lain seperti green ICT, green IT yaitu merupakan hal yang mengacu pada sekumpulan dari teknologi informasi dan komunikasi (TIK) yang ramah lingkungan, yang membantu individu dan organisasi memelihara energi dan mengurangi dampak yang merugikan bagi lingkungan. Selain itu, green computing juga merupakan usaha bagaimana memanfaatkan TIK dengan cara yang ramah lingkungan (Ryoo et al, 2011). Hal lain yang dapat dicapai dari implementasi komputasi hijau adalah viabilitas ekonomi serta meningkatkan performa sistem dan penggunaan sementara memenuhi tanggung jawab dan etika sosial (Sheikh et al, 2010).

Terdapat beberapa pendekatan komputasi hijau yang dapat diterapkan, seperti pada pendekatan holistik yang dikemukakan Murugesan, di mana komputasi hijau meliputi empat pendekatan seperti: green use (reduksi energi), green disposal (reduksi limbah perangkat), green design (desain perangkat/komponen/infrastruktur hemat energi), green manufacturing (minimalisasi dampak pembuatan perangkat elektronik terhadap lingkungan).

Pentingnya komputasi hijau seperti yang diungkapkan pada artikel Navdeep Kochhar et al (2011) tentang beberapa fakta 
menarik bagaimana komputer berpengaruh terhadap lingkungan beberapa di antaranya adalah:

- Rata-rata sebuah komputer desktop membutuhkan 85 watt dalam keadaan idle meskipun layar monitor tidak menyala. Jika komputer tersebut idle dalam waktu hanya 40 jam di samping 168 jam penuh dalam seminggu, lebih dari 40 dolar biaya untuk energi yang dapat diselamatkan setiap tahunnya.

- $\quad$ Satu komputer yang dibiarkan menyala 24 jam sehari membutuhkan biaya antara 115 sampai 160 dolar biaya energi per tahunnya selain juga membentuk 1500 pound $\mathrm{CO} 2$ di atmosfir.

- Sebuah pohon akan menyerap 3-15 pound $\mathrm{CO} 2$ per tahun. Hal ini berarti dibutuhkan sampai 500 pohon untuk menyerap emisi $\mathrm{CO} 2$ per tahun dari satu komputer yang menyala sepanjang hari.

Dari fakta tersebut, terlihat bahwa sangat diperlukan kesadaran bagi para pengguna TIK untuk menggunakan perangkatnya secara bijak. Bahkan dampak yang akan terasa dalam bentuk kerusakan lingkungan juga bisa disebabkan oleh pola penggunaan yang kurang bijak.

\section{METODE PENELITIAN}

Penelitian dengan pendekatan kualitatif ini dilakukan dengan diskusi kelompok terarah dengan perwakilan pada kedua elemen instansi tersebut (pemerintahan dan bisnis) yang menjadi informan kunci yaitu para pengelola infrastruktur TIK sekaligus yang menjadi representasi dari instansinya masingmasing. Dari sisi pemerintah daerah, instansi yang menjadi objek penelitian ini antara lain: Diskominfo Pemprov Jabar, Diskominfo Pemkot Bandung, Diskominfo Pemkot Bogor, Humas Kota Bogor, Diskominfo Pemkab Garut, dan Bappeda Kabupaten Garut. Sedangkan dari instansi bisnis antara lain: PT. Melvar Lintasnusa (Melsa), PT. Cipta Jelajah Informatika (CIFO), PT. Bogor Net (Bonet), Biznet Bogor, PT. Graha Citra, dan Masagi Solusi.
Instrumen yang terdapat pada penelitian ini sama halnya dengan yang dilakukan pada penelitian sebelumnya tentang komputasi hijau di lingkungan perguruan tinggi dengan mengambil kesadaran sebagai instrumen utama (Nugroho, 2012). Secara garis besar penelitian ini mengambil satu instrumen utama yang ingin diketahui dalam upaya komputasi hijau yang sedang berjalan dan yang akan direncanakan di pemerintah daerah dan sektor bisnis yaitu: kesadaran. Bisa dikatakan bahwa kesadaran merupakan salah satu hal mendasar dalam implementasi komputasi hijau. Seperti yang diungkapkan Gheewala et al (2011) "With the increase in awareness of global warning, individuals and organizations have started taking steps towards greening the environment. Several standardization bodies like The Global ICT Standardization Forum for India (GISFI), the European Telecommunication Standardization Institute (ETSI) etc. lead the greening of ICT."

Murugesan (2011) mengatakan:"As we see it, the key to enterprise greening IT success is creating environmental (green) awareness among employees, making right decisions, leveraging leading-edge technologies and sustainable practices to help the company achieve its green goals without impacting on performance."

Selanjutnya diambil empat bentuk instrumen lain yang dirasakan berkaitan dengan bentuk dari instrumen kesadaran. Keempat instrumen tersebut antara lain: pengetahuan (knowledge) dari pemerintahan dan sektor bisnis, infrastruktur, kebijakan, serta praktik (perilaku) yang menjadi kebiasaan (habit) para pegawai di masingmasing instansi. Gambar 1 adalah bagan secara garis besar dari instrumen yang diberikan pada saat FGD.

Selanjutnya, dalam penelitian ini dilakukan observasi yang mengambil beberapa indikator antara lain: lingkungan kerja dari setiap instansi dan infrastruktur pusat data (data center). Observasi di lingkungan kerja bertujuan untuk melihat bagaimana para pegawai memanfaatkan perangkat TIK yang ada, melihat kondisi lingkungan kerja seperti pencahayaan dan 


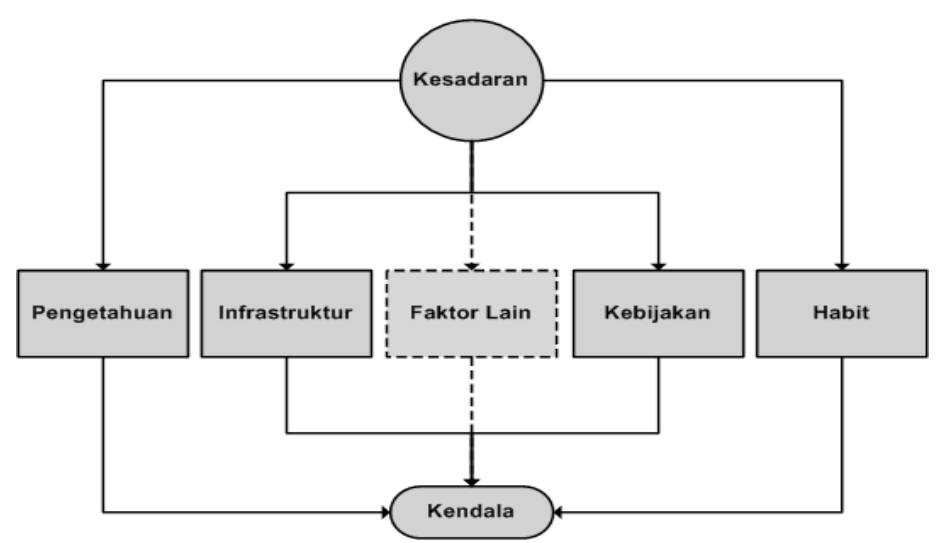

Sumber: hasil pemikiran penulis

Gambar 1

Ilustrasi Instrumen Diskusi Kelompok Terarah

Tabel 1

Perkiraan Konsumsi Daya dari Suatu Perangkat Keras

\begin{tabular}{lccc}
\hline Component & Idle Power Usage & Average Power Usage & Maximum Power Usage \\
\hline Server 1 & 383.75 & 454.39 & 600 (estimated) \\
CPU & 40.8 & 130 \\
HDD & 14.35 & 17 \\
Dimm 1 & 3 & 3 \\
Dimm 2 & 3 & 3 \\
Video & 18.3 & 25.6 \\
Network Card & 4.95 & 4.95 \\
CD/DVD & 2 & 18 \\
\hline
\end{tabular}

Sumber : "Sample Hardware Energy Usage Profile (in watts)" Rajesh Chheda et al., 2011

pendingin ruangan, serta bagaimana manajemen perangkat TIK yang digunakan apakah sudah mendukung upaya implementasi komputasi hijau atau belum.

Observasi pada lingkungan infrastruktur pusat data ditujukan untuk melihat beberapa hal yang dapat menjadi indikator: bagaimana upaya setiap instansi untuk melakukan penghematan pada sisi infrastruktur pusat data dengan melakukan virtualisasi server, manajemen daya pusat data, perencanaan tata letak, kondisi infrastruktur dan lingkungannya apakah juga telah mendukung komputasi hijau atau tidak. Hal yang mendasari dilakukannya observasi pada pusat data adalah di mana pusat data dapat mengonsumsi daya hampir 10-30 kali setiap kaki persegi lebih banyak daripada ruang kerja (Caldow, 2008), serta semakin tinggi dan meningkatnya konsumsi energi membuat pusat data menjadi sumber dari gas rumah kaca (Harmon et al, 2009).

Konsumsi daya pada lingkungan data center (server) merupakan hal yang paling signifikan pada bidang infrastruktur TIK. Disebutkan bahwa konsumsi satu perangkat server dalam kondisi idle mencapai sekitar 383.75 watt, penggunaan secara umum mencapai 454.39 watt dan penggunaan secara maksimum membutuhkan daya sekitar 600 
watt (Chheda et al, 2011). Tabel 1 diuraikan mengenai perkiraan konsumsi daya dari suatu sampel infrastruktur TIK. Tabel tersebut memperlihatkan, bahwa semakin banyak jumlah server dapat memberikan pengeluaran yang jauh semakin besar. Implementasi dari virtualisasi server pada seluruh instansi perlu untuk dilihat pada saat dilakukan observasi. Dengan penghematan jumlah perangkat server tersebut berarti akan mengoptimalkan kinerja dari suatu server, melakukan penghematan belanja, dan penghematan daya sekaligus meningkatkan kualitas tata kelola infrastruktur TIK pada suatu instansi yang di observasi.

\section{HASIL PENELITIAN DAN PEMBAHASAN}

\section{Perbandingan Faktor Pengetahuan dan Sumber Daya Manusia (SDM)}

Pada elemen pemerintahan, komputasi hijau masih merupakan sesuatu yang baru atau belum familiar. Komputasi hijau lebih diketahui sebagai komputasi ramah lingkungan yang menekankan pada penghematan daya. Kebutuhan akan adanya sosialisasi dan transfer knowledge tentang komputasi hijau kepada para pemangku kebijakan, pengelola infrastruktur TIK serta SDM yang ada di dalam instansi pemerintah daerah sangat dibutuhkan baik yang bersifat umum ataupun hal-hal teknis yang mendukung implementasi komputasi hijau.

Porsi (jumlah) SDM bidang Kominfo di lingkungan pemerintah daerah juga belum mencukupi, hal ini juga menjadi kendala tidak hanya dalam implementasi komputasi hijau, akan tetapi juga pada bidang Kominfo lainnya. Secara keseluruhan lingkungan kerja suatu pemerintah daerah yang merupakan sekumpulan pegawai dengan latar belakang yang sangat beragam dengan pola pikir yang tidak selalu sama juga menjadi kendala untuk mengimplementasikan komputasi hijau. Kendala-kendala mendasar inilah yang juga menyebabkan beberapa program yang mendukung komputasi hijau seperti sistem pelayanan dan sistem kantor secara paperless masih belum sepenuhnya dapat berjalan selain dari faktor regulasi itu sendiri.

Pada elemen bisnis, komputasi hijau sudah dikenal dan langkah-langkahnya sudah diterapkan meskipun terdapat pertimbanganpertimbangan bagi perusahaan IT untuk menerapkan komputasi hijau secara penuh. Pemahaman tentang komputasi hijau dari karyawan membuat penerapan komputasi hijau bisa dikatakan berjalan secara sadar dan tidak sadar. Inisiatif yang terbentuk karena adanya pengetahuan tentang komputasi hijau membuat penerapan beberapa langkah komputasi hijau sudah berjalan dengan baik di lingkungan perusahaan IT. Penggunaan teknologi internet untuk komunikasi resmi, dan pemanfaatan teknologi lain seperti VoIP sampai dengan virtual server juga sudah umum diterapkan di lingkungan bisnis.

\section{Perbandingan Faktor Kebijakan}

Pada elemen pemerintahan, komputasi hijau belum menjadi program dari instansi di pemerintah daerah tersebut. Kebijakan yang masih kental bersifat top-down membuat dinas-dinas pada penelitian ini masih menunggu sosialisasi ataupun edaran dari kementerian terkait dalam hubungannya dengan penerapan komputasi hijau di lingkungan pemerintahan. Ini dapat dikatakan, belum ada tujuan yang jelas tentang penerapan komputasi hijau di lingkungan pemerintah daerah di Jawa Barat.

Akan tetapi, sudah banyak upaya yang dilakukan oleh elemen pemerintahan untuk melakukan efisiensi. Implementasi LPSE (Layanan Pengadaan Secara Elektronik) sudah dilakukan oleh instansi pemerintahan. Adanya LPSE ini dapat dilakukan banyak penghematan kertas dibandingkan dengan layanan pengadaan secara konvensional.

Layanan lain yang bersifat paperless seperti e-office masih dilakukan secara bertahap (sebagian). Pengadaan perangkat TIK yang berdaya rendah sudah mulai dilakukan, beralihnya penggunaan monitor CRT menuju ke monitor LCD juga masih dilakukan secara bertahap. Seperti terlihat pada gambar 2 . 


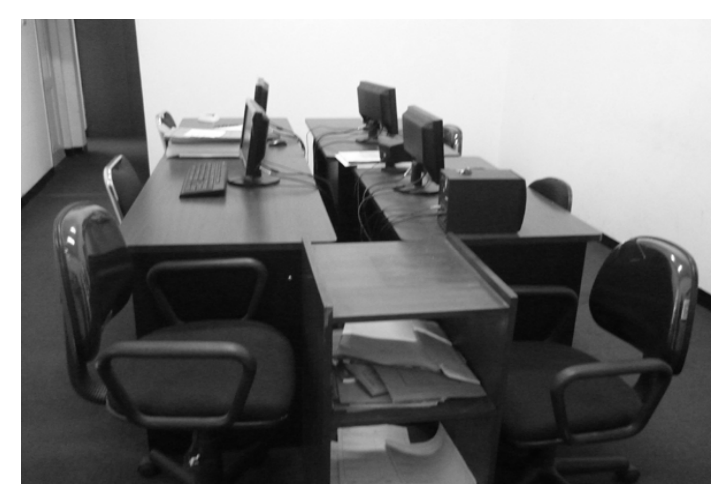

Sumber : hasil observasi 2012

Gambar 2

Ruang Kerja LPSE

Implementasi virtual server belum sepenuhnya berjalan meskipun pada umumnya pengelolaan sistem infrastruktur IT pada masing-masing Pemda sudah dikelola sendiri dan berada dalam satu area lingkungan kerja. Penggunaan email sebagai bentuk komunikasi juga belum dapat menggantikan bentuk komunikasi konvensional yang masih menggunakan kertas.

Sedangkan dari elemen bisnis, komputasi yang ramah lingkungan dan penghematan daya sangatlah membantu untuk pengurangan pengeluaran perusahaan (adanya efisiensi) yang pada akhirnya dapat meningkatkan profit dari perusahaan tersebut. Di sini sektor bisnis dirasakan lebih baik dalam hal kebijakan efisiensi karena banyak hal yang diterapkan untuk sebagai upaya yang mengarah ke komputasi hijau meskipun sebenarnya banyak perusahaan tidak memiliki tujuan khusus ke komputasi hijau. Pada umumnya belum ada program khusus menuju komputasi hijau dari sebagian besar pelaku sektor bisnis. Dari faktor efisiensi dan peningkatan layanan yang bertujuan meningkatkan profit adalah faktor utama yang menjadi penggerak dari sektor bisnis meskipun dalam suatu kondisi faktor profit tersebut berkebalikan dengan konsep komputasi hijau. Akan tetapi, hanya sebagian kecil dari objek penelitian dari sektor bisnis ini yang mempromosikan konsep ramah lingkungan sebagai pendukung produknya.
Sebagian besar objek penelitian dari sektor bisnis di sini tidak memiliki pola pikir yang mengarah kelestarian lingkungan secara langsung, sektor bisnis pada penelitian ini telah melakukan efisiensi dari pengadaan perangkat infrastruktur TIK (perangkat dengan performa tinggi tetapi dengan biaya yang rendah), implementasi virtual server, implementasi VoIP, penggunaan terminal (virtual desktop) serta pengembangan sistem informasi yang menjadi langkah awal dari bentuk efisiensi di sektor bisnis yang tidak mengorbankan performanya. Pemilihan perangkat kerja dan infrastruktur menjadi pertimbangan utama dalam hal efisiensi. Faktor performa barang, harga, spesifikasi, mobilitas dan fungsionalitas biasanya menjadi acuan bagi para pengelola TIK di sektor bisnis untuk menetapkan pilihannya.

\section{Perbandingan Faktor Habit (Kebiasaan)}

SDM di lingkungan pemerintahan lebih banyak bergerak pada saat ada keputusan. Selain itu, tidak adanya faktor profit and cost di instansi pemerintahan menjadikan mindset akan efisiensi belum sepenuhnya diterapkan. Dari hasil observasi, terlihat masih seringnya SDM di lingkungan Pemda yang meninggalkan komputer dengan keadaan monitor masih menyala. Belum adanya komitmen dari suatu imbauan atau kebijakan juga menjadi kendala dalam mengubah habit SDM yang ada. Pejabat terkait, juga tidak memungkiri bahwa imbauan yang ada pada 


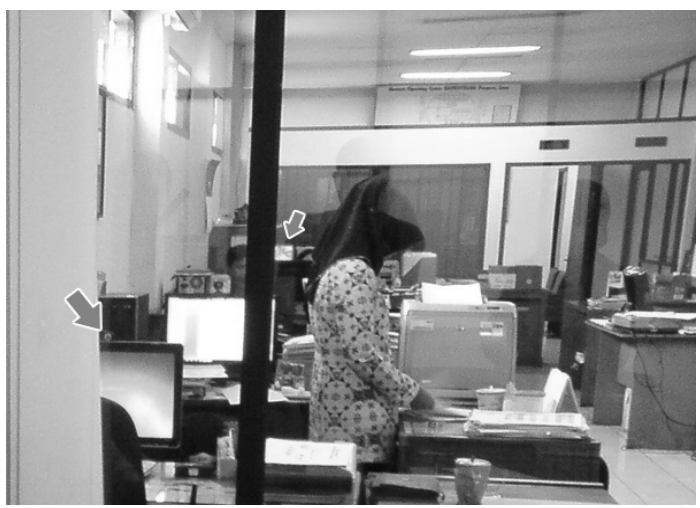

Sumber: hasil observasi 2012

Gambar 3

Habit dari Terlewatnya Penerapan Komputasi Hijau di Salah Satu Pemda

akhirnya tidak terimplementasikan seperti apa yang diinginkan. Gambar 3 merupakan salah satu hal yang terlewat di lingkungan Pemda terhadap penerapan komputasi yang ramah lingkungan, di mana masih adanya monitor komputer yang menyala seperti yang ditunjukkan dengan tanda panah ketika para pegawai tidak sedang berada di meja kerjanya.

Hal lain yang berbeda antara pemerintahan dan bisnis dalam hal mengubah kebiasaan di sini adalah adanya reward and punishment. Di pemerintahan reward and punishment belum banyak diberikan pada para karyawannya, sementara di sektor bisnis penerapan reward and punishment sudah dilakukan. Regulasi yang mengatur reward and punishment sampai pada pekerjaan yang kecil ternyata dapat membantu mengubah kebiasaan SDM dan peningkatan inisiatif di lingkungan kerjanya. Pembentukan kebiasaan dari kedua elemen ini memang sangat terlihat berbeda. Perusahaan IT lebih ketat dalam membentuk kebiasaan SDMnya dibandingkan dengan Pemda. Setiap langkah yang dapat mengurangi pengeluaran (cost) seperti efisiensi lampu, pendingin ruangan, penggunaan komputer, pencetakan kertas, sampai dengan berkomunikasi menggunakan internet pada perusahaan IT sudah banyak diterapkan dan kesadaran untuk melakukan efisiensi seperti itu sudah menjadi kebiasaan bagi SDMnya.

\section{Perbandingan Faktor Infrastruktur}

Faktor infrastruktur dari perusahaan IT dalam implementasinya bisa dikatakan berada di depan infrastruktur Pemda setempat. Secara keseluruhan, kedua elemen ini sudah memiliki infrastruktur yang mengarah kepada komputasi hijau. Penggunaan monitor dengan daya yang rendah seperti LCD dan LED, penggunaan laptop serta virtual desktop sebagai perangkat untuk bekerja, dan mayoritas sudah menggunakan blade server sebagai ganti dari perangkat server yang ada sebelumnya.

Akan tetapi di sisi lain, perusahaan IT seringkali melakukan peningkatan performa (kualitas) layanan atau produknya bagi pelanggan tetapi peningkatan performa ini tidak jarang harus mengorbankan maksud dari komputasi hijau demi meningkatkan profit perusahaan. Faktor cost juga tidak jarang berkebalikan dengan maksud komputasi hijau. Pemilihan perangkat yang lebih murah dengan performa yang tidak jauh berbeda atau bahkan sama dengan perangkat yang lebih mahal akan menjadi pilihan dari sektor bisnis meskipun perangkat tersebut tidak lebih ramah lingkungan dibandingkan perangkat yang lebih mahal.

Sementara itu di lingkungan Pemda, infrastruktur yang ada cenderung masih belum optimal dari sisi daya guna ataupun perawatannya.

Hal ini merupakan imbas dari kurangnya SDM di bidang informatika serta 


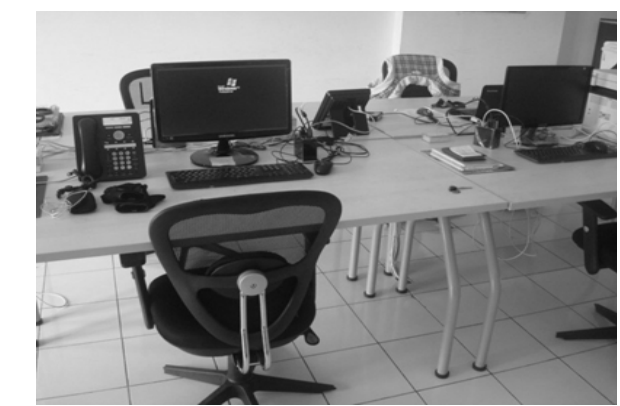

Sumber: hasil observasi 2012

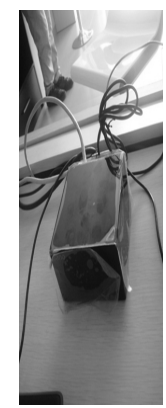

Gambar 4

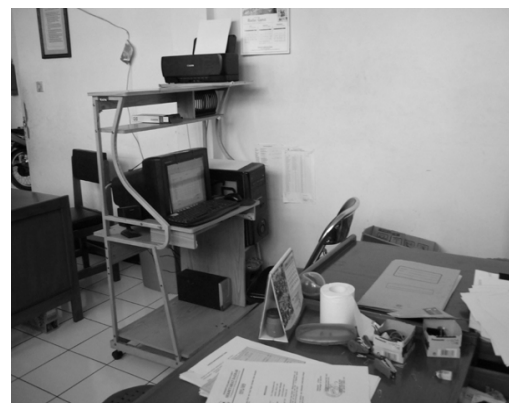

Sumber: hasil observasi 2012
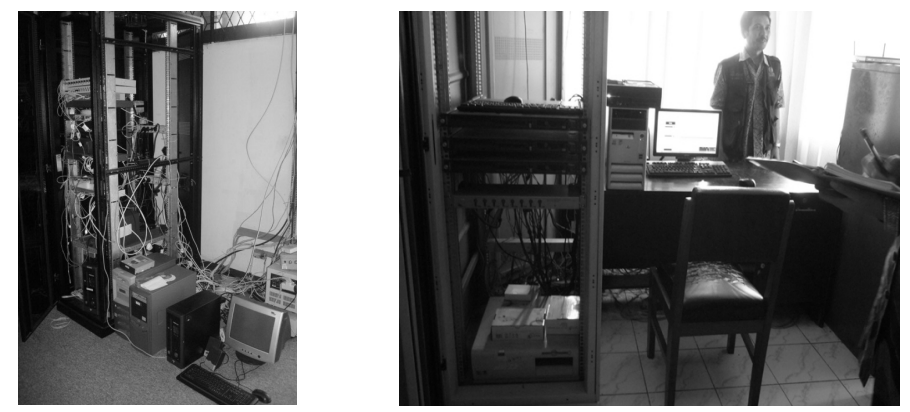

\section{Gambar 5}

Pengelolaan Infrastruktur dengan Konsep Reuse, belum Optimalnya Pengelolaan Server di Lingkungan Pemda dan Mulai Beralihnya ke Perangkat Blade Server

pengetahuan tentang bidang IT khususnya komputasi hijau yang juga masih belum akrab didengar. Salah satu konsep komputasi hijau yang berjalan di lingkungan Pemda dari sisi infrastruktur bisa dikatakan belum banyak berjalan. Konsep penggunaan kembali (reuse) dari perangkat yang sudah lama untuk digunakan kembali sudah menjadi bentuk efisiensi belanja perangkat yang mengarah ke komputasi hijau dari instansi Pemda. Akan tetapi konsep reuse ini juga masih menyisakan sedikit kendala di mana masih ada perangkat seperti monitor CRT yang masih digunakan. Gambar 4 dan 5 memperlihatkan infrastruktur di sektor bisnis dan sektor Pemda.

\section{Edaran dan Sosialisasi tentang Komputasi Hijau bagi Pemda}

Konsep regulasi yang cenderung bersifat top-down dan tidak adanya konsep profit and cost serta minimnya reward and punishment di lingkungan Pemda menjadi faktor belum tingginya kesadaran ataupun inisiatif untuk melakukan komputasi yang ramah lingkungan.

Transfer knowledge (sosialisasi) tentang komputasi hijau bagi SDM di tataran Pemda menjadi salah satu cara agar konsep komputasi hijau lebih dikenal. Banyak sekali langkah sederhana dari komputasi hijau yang seringkali kurang diperhatikan karena kurangnya wawasan dari SDM yang ada. Para pemangku kebijakan dari setiap Pemda serta para pengelola infrastruktur TIK hendaknya menjadi sasaran dari program sosialisasi ini. Salah satu ukuran yang mungkin dapat dilihat dari berjalannya komputasi hijau di lingkungan pemerintahan adalah berjalannya konsep e-office dan semakin sadarnya SDM di lingkungan Pemda untuk lebih 
mengupayakan proses komputasi yang ramah lingkungan.

\section{Komputasi Hijau Sebagai Dukungan Produk Bagi Sektor Bisnis}

Di Jawa Barat, komputasi hijau memang belum menjadi suatu tujuan atau program bagi perusahaan TIKnya. Akan tetapi ketika menilik ke negara-negara maju, komputasi hijau yang dikenal dengan green computing sudah menjadi satu daya promosi dari perusahaan di bidang TIK untuk mendukung produknya. Dilakukannya komputasi hijau di negara maju menjadi satu nilai lebih bagi perusahaan yang menerapkan. Selain efisiensi yang dapat meningkatkan keuntungan perusahaan, penerapan teknologi yang lebih ramah lingkungan dapat meningkatkan citra perusahaan TIK tersebut dibandingkan dengan perusahaan yang tidak menerapkan teknologi yang ramah lingkungan.

Banyaknya perusahaan di bidang TIK di Indonesia merupakan salah satu peluang yang sangat baik untuk mengampanyekan komputasi hijau. Seperti yang terlihat pada hasil penelitian ini, sektor bisnis pada umumnya sudah menerapkan langkahlangkah efisiensi yang sebenarnya telah mengarah ke konsep komputasi hijau, dan hal ini perlu didukung juga dengan pemahaman SDM tentang komputasi hijau serta kebiasaan SDM. Hanya saja mayoritas perusahaan di bidang TIK yang menjadi objek penelitian ini masih belum memiliki arah (program) menuju konsep yang ramah lingkungan.

\section{PENUTUP}

\section{Simpulan}

Kesadaran sebagai upaya penerapan komputasi hijau di lingkungan Pemerintah Daerah di Jawa Barat belum menjadi budaya kerja yang dianut. Terdapat beberapa faktor yang menghambat dari berjalannya konsep ini adalah: faktor regulasi / program / kebijakan yang masih bersifat top-down membuat SDM yang ada di lingkungan Pemda belum menjalankan konsep komputasi hijau. Hal ini juga didukung dengan tidak adanya faktor profit and cost dari Pemda yang juga menyebabkan minimnya inisiatif bagi SDM di dalamnya untuk lebih efisien dalam penggunaan perangkat TIKnya. Faktor lain yang menjadi kendala adalah kurangnya jumlah SDM di lingkungan Pemda di bidang TIK serta pengenalan konsep komputasi hijau yang relatif baru terdengar.

\section{Saran}

Dari beberapa kendala tersebut, pelaksanaan upaya yang mengarah pada konsep komputasi hijau di lingkungan Pemda dirasakan masih minim. Adapun beberapa upaya yang sampai saat ini sudah dilakukan antara lain adalah: konsep penggunaan (reuse) kembali perangkat TIK yang ada, beralihnya ke sistem paperless yang masih berjalan bertahap (sebagian), mulai beralih ke infrastruktur blade server yang menghemat jumlah server fisik dari instansi Pemda tersebut, adanya kebijakan yang masih berupa imbauan terhadap penghematan daya, dan implementasi layanan secara elektronik yang dalam hal ini masih berupa layanan lelang elektronik (LPSE).

Upaya penerapan komputasi hijau di sektor bisnis di Jawa Barat sudah mulai berjalan dengan baik meskipun sebenarnya tidak ada program khusus dari perusahaan yang mengarah ke komputasi hijau. Kebijakan untuk menekan pengeluaran (melakukan efisiensi) menjadi pendorong SDM di dalam perusahaan tersebut untuk lebih berhemat dalam penggunaan daya dan pengeluaran lainnya yang sudah menjadi kebiasaannya. Hal ini juga diperkuat adanya konsep reward and punishment yang mau tidak mau memaksa SDM pada perusahaan tersebut agar lebih menjalankan aturan yang ada. Hal lain yang mendukung berjalannya konsep komputasi hijau di sektor bisnis adalah wawasan dari SDM yang sudah mulai memahami beberapa langkah komputasi hijau yang dapat dijalankan di perusahaannya.

Pelaksanaan upaya penerapan komputasi hijau di lingkungan perusahaan di bidang TIK di Jawa Barat pada umumnya seperti: penggunaan media digital (internet) 
sebagai media komunikasi resmi secara internal (konsep paperless yang berjalan lebih baik dibandingkan Pemda), konsep reuse pada beberapa perangkat TIK, sudah menggunakan blade server, implementasi virtual server dan virtual desktop, adanya kebijakan untuk penghematan daya, penggunaan teknologi VoIP, sampai dengan perawatan dan pengelolaan perangkatperangkat TIK yang lebih baik dibandingkan Pemda. Dengan adanya langkah-langkah menuju komputasi hijau yang telah dijalankan di sektor bisnis, Kemkominfo dapat memberikan dukungan terhadap perusahaan yang sudah mengarah ke implementasi komputasi hijau. Adanya dukungan ini dapat menjadi rangsangan bagi perusahaan di bidang TIK maupun perusahaan di bidang lain untuk turut serta menjalankan konsep komputasi hijau yang mana dapat memberikan suatu nilai lebih bagi perusahaan itu sendiri.

\section{DAFTAR PUSTAKA}

\section{Buku:}

Murugesan, San. (2008). Harnessing Green IT: Principles and Practices. IEEE IT Professional, January-February 2008

Gheewala, Dheepa; Gheewala, Vivek. (2011). Understanding the Context of Green ICT Handbook Research On Green ICT Technology, Business and Social Perspectives. 2011. Information Science Reference.

Murugesan, San. (2011). Strategies for Greening Enterprise IT: Creating Business Value and Contributing to Environmental Sustainability. Handbook Research On Green ICT Technology, Business and Social Perspectives. 2011, Information Science Reference.

Ryoo, Jungwoo; Choi, Young B., \& Oh, Tae H. (2011). A Taxonomy of Green Information and Communication Protocols and Standards, Handbook Research On Green ICT Technology,
Business and Social Perspectives, Information Science Reference.

\section{Sumber lainnya:}

Jurnal :

Chheda, Rajesh; Shookowsky, Dan; Stefanovich, Steve; Toscano, Joe. (2008) Profiling Energy Usage for Efficient Consumption. The Architecture Journal, Vol 18, pp. 24 Green Computing, Microsoft Inc. 2008.

Kochhar, Navdeep; Garg, Aarun. (2011) EcoFriendly Computing: Green Computing. International Journal of Computing and Business Research ISSN (Online), Volume 2 Issue 2 May 2011, pp. 22296166.

Sheikh, A. Riyaz \& Lanjewar, U. A. (2010) Green Computing- Embrace a Secure Future. International Journal of Computer Applications (0975 - 8887) Volume 10- N.4. November 2010.

\section{Prosiding :}

Harmon, R. Robert; Auseklis, Nora. (2009) Sustainable IT Services: Assessing the Impact of Green Computing Practices. Proceedings PICMET.

Nugroho, Badar Agung. (2012) Analisa Kesadaran Upaya Penerapan Komputasi Hijau di Lingkungan Kerja Perguruan Tinggi (Studi Kasus di 6 Perguruan Tinggi di Jawa Barat), Prosiding Seminar Pemanfaatan Teknologi Informasi dan Komunikasi Dalam Meningkatkan Nilai Tambah Pelayanan Publik Guna Mewujudkan Masyarakat Berbasis Informasi, editor Haryati. Bandung: BPPKI.

\section{Internet :}

Caldow, J. (2008), The greening of Government: a study of how governments define the green agenda, p. 8, available at: <www01.ibm.com/industries/government/ieg/ pdf/green_gov_agenda.pdf $>$. 